\title{
Omnivorous shrimp Neocaridina denticulata sinensis enhances the growth of submerged macrophyte Vallisneria denseserrulata
}

\author{
Jialiang Ye ${ }^{1}$, Yali Tang ${ }^{1}$, Xiufeng Zhang ${ }^{1}$, Ping Zhong ${ }^{1}$ and Zhengwen Liu ${ }^{1,2,3, *}$ \\ ${ }^{1}$ Department of Ecology and Institute of Hydrobiology, Jinan University, Guangzhou 510632, PR China \\ 2 State Key Laboratory of Lake Science and Environment, Nanjing Institute of Geography \& Limnology, Chinese Academy of Sciences, \\ Nanjing 210008, PR China \\ 3 Sino-Danish Center, University of the Chinese Academy of Sciences, Beijing 101408, PR China
}

Received: 13 March 2019 / Accepted: 7 June 2019

\begin{abstract}
Lake eutrophication often causes declines and even losses of submerged macrophytes through the shading effects of increased periphyton and phytoplankton. The Chinese swamp shrimp Neocaridina denticulata sinensis Kemp (Decapoda, Atyidae) is a common omnivore in Chinese lakes, where its presence may impact both periphyton and phytoplankton, with previously unstudied consequences for submerged macrophytes. Here, using a mesocosm experiment, we studied the effect of $N$. $d$. sinensis on periphyton, phytoplankton and the submerged macrophyte Vallisneria denseserrulata. Results showed that in the presence of $N$. $d$. sinensis, the biomass of periphyton on the leaves of $V$. denseserrulata was significantly reduced, and that growth rate of $V$. denseserrulata increased. The presence of $N$. $d$. sinensis also significantly increased the total phosphorus concentrations in the water column and phytoplankton biomass (chlorophyll- $a$ ). The enhanced growth of $V$. denseserrulata is likely to be linked to improved light harvesting due to the reduced periphyton attached to their leaf surface. The results suggest that stocking with Chinese swamp shrimps may enhance the development of macrophytes in eutrophic shallow lakes.
\end{abstract}

Keywords: omnivorous shrimp / submerged macrophytes / periphyton / eutrophication

\begin{abstract}
Résumé - La crevette omnivore Neocaridina denticulata sinensis favorise la croissance du macrophyte submergé Vallisneria denseserrulata. L'eutrophisation des lacs entraîne souvent des déclins, voire des pertes de macrophytes submergés en raison des effets d'ombrage dus à l'augmentation du périphyton et du phytoplancton. La crevette des marais chinois Neocaridina denticulata sinensis Kemp (Decapoda, Atyidae) est un omnivore commun dans les lacs chinois, où sa présence peut avoir un impact sur le périphyton et le phytoplancton, avec des conséquences non étudiées auparavant pour les macrophytes immergés. Ici, à l'aide d'une expérience en mésocosme, nous avons étudié l'effet de $N$. $d$. sinensis sur le périphyton, le phytoplancton et le macrophyte immergé Vallisneria denseserrulata. Les résultats ont montré qu'en présence de $N$. $d$. sinensis, la biomasse de périphyton sur les feuilles de $V$. denseserrulata était considérablement réduite et que le taux de croissance de $V$. denseserrulata augmentait. La présence de $N$. $d$. sinensis a également augmenté de façon significative les concentrations de phosphore total dans la colonne d'eau et la biomasse phytoplanctonique (chlorophylle- $a$ ). La croissance accrue de $V$. denseserrulata est probablement liée à une meilleure captation de la lumière en raison de la réduction du périphyton attaché à la surface de leurs feuilles. Les résultats suggèrent que l'ensemencement de crevettes des marais chinois pourrait favoriser le développement de macrophytes dans les lacs eutrophes peu profonds.
\end{abstract}

Mots clés : crevette omnivore / macrophyte submergé / périphyton / eutrophisation

*Corresponding author: zliu@niglas.ac.cn 


\section{Introduction}

Submerged macrophytes are important primary producers in shallow lake ecosystems, playing a key role in maintaining clear water states through the assimilation of nutrients, accelerating the deposition of suspended solids and preventing the resuspension of sediments (Jaynes and Carpenter, 1986; Jeppesen et al., 1990; van Donk and van de Bund, 2002). Replanting with submerged macrophytes has been an important tool in the restoration of shallow eutrophic lakes (Yu et al., 2016; Liu et al., 2018).

Eutrophication often enhances the growth of periphyton on the surfaces of submerged macrophytes, reducing the availability of light and inorganic nutrients to the affected plant. Overgrowth of periphyton is thus a major cause of loss and decline of submerged lake macrophytes under eutrophic conditions (Hough et al., 1989; Jones et al., 2002; Phillips et al., 2016). Many previous studies have also shown that reducing the biomass of periphyton can promote growth of submerged macrophytes (Daldorph and Thomas, 1995; Asaeda et al., 2004; Li et al., 2008). Li et al. (2008) showed that periphyton-feeding by snails can boost submerged macrophytes growth in exactly this way, and a variety of aquatic grazing invertebrates have been suggested as potential aids in the management of submerged macrophytes in shallow lake systems (Daldorph and Thomas, 1995; Rao et al., 2015).

Omnivorous shrimps that consume leaf litter, particulate matter, and periphyton are common in many freshwater ecosystems (Pringle et al., 1993; Asaeda et al., 2004; Sultana et al., 2010), and have been shown to exert a variety of ecological effects (Pringle et al., 1993; Crowl et al., 2001; Geddes and Trexler, 2003; Souza and Moulton, 2005; Moulton et al., 2012). While some previous studies have demonstrated a significant reduction of periphyton biomass as a result of direct grazing by omnivorous shrimps (Geddes and Trexler, 2003; Moulton et al., 2012), others have recorded significant increases in depositional material and periphyton on substrata when shrimps are present (Pringle et al., 1993; Geddes and Trexler, 2003). These increases are probably stimulated by nutrients excreted by the shrimps and by the mechanical resuspension of sediment (Geddes and Trexler, 2003).

The Chinese swamp shrimp Neocaridina denticulata sinensis Kemp (Decapoda, Atyidae) is common in East Asia. It is also found as an invasive species in Europe (Weiperth et al., 2019) and the Hawaiian Islands (Englund and Cai, 1999). The species is commercially important in lake fisheries in China despite its small size (Li et al., 1990), but its ecological role on lake systems has not been evaluated. We hypothesized that grazing by $N$. $d$. sinensis can reduce the periphyton biomass and thus enhance the growth of submerged macrophytes, while nutrient concentrations in the water may increase due to shrimp activities. The results provide insights that might be important for the management of submerged macrophytes and the restoration of eutrophic shallow lakes in the region.

\section{Materials and methods}

\subsection{Materials}

Specimens of the Chinese swamp shrimp $N$. d. sinensis were purchased from Guangzhou Huadiwan Aquarium,
Guangzhou, China. They were $1.5-2.0 \mathrm{~cm}$ long and weighed between 0.3 and $0.5 \mathrm{~g}$. Samples of sediment and of the submerged macrophyte Vallisneria denseserrulata were collected from the South Lake of Jinan University. The plants were rinsed thoroughly to remove the periphyton.

\subsection{Experiment design and sampling}

The experiment was conducted outdoors in eight polyethylene plastic tanks set up in the grounds of Jinan University, Guangzhou, China. The tanks were $60 \mathrm{~cm}$ high, with a volume of 75 liters. A five-centimeter depth of sediment $\left(\mathrm{TN}=1.84 \mathrm{mg} \mathrm{g}^{-1}, \mathrm{TP}=1.46 \mathrm{mg} \mathrm{g}^{-1}\right)$ was added to each tank, and 45 centimeters of tap water $\left(\mathrm{TN}=1.91 \mathrm{mg} \mathrm{L}^{-1}, \mathrm{TP}=0.04\right.$ $\left.\mathrm{mg} \mathrm{L}^{-1}\right)$. The experiment involved four replicates of two different treatments: macrophytes with shrimps (SM) and macrophytes without shrimps (NS). At the beginning of the experiment, we planted about 29 grams (fresh weight) $V$. denseserrulata into each tank, and eight shrimps were added to each SM treatment tanks which resulted in a shrimp density within the natural arrange (Oh et al., 2003). The tank water temperature ranged from 17 to $30^{\circ} \mathrm{C}$ during the experiment.

Samples of periphyton and water were collected one week after the experiment began, and then every two weeks thereafter, and the experiment lasted for 17 weeks (119 days). At each sampling, three leaves were randomly taken from each tank, and the periphyton attached to each leaf was brushed and rinsed into a beaker using pure water, which was later filtered by $\mathrm{GF} / \mathrm{C}$ filter. As a proxy for periphyton biomass, the chlorophyll- $a$ (Chl- $a$ ) content of the matter retained on the filter was measured spectrophotometrically, after extraction in a $90 \%$ (v/v) acetone/water solution for $24 \mathrm{~h}$. No correction was carried out for pheophytin interference (SEPA, 2002). The lengths and widths of the sampled leaves were measured and used to calculate leaf surface area and the biomass of periphyton was expressed as chlorophyll- $a(\mu \mathrm{g})$ per unit leaf surface area $\left(\mathrm{cm}^{2}\right)$. Water samples were taken and analyzed for total nitrogen (TN), total phosphorus (TP), total dissolved nitrogen (TDN), total dissolved phosphorus (TDP) and Chl- $a$ content in the laboratory according to Chinese standard methods (Jin and Tu, 1990), and Chl- $a$ was analyzed using the method described for periphyton above. At the end of the experiment, all $V$. denseserrulata were harvested and their total fresh weight recorded. The relative growth rate (RGR) of $V$. denseserrulata was calculated using the formula RGR $\left(\mathrm{mg} \mathrm{g}^{-1} \mathrm{~d}^{-1}\right)=1000 \times \ln (\mathrm{Wf} / \mathrm{Wi}) /$ days, where Wf $(\mathrm{g})$ and Wi (g) were final and initial total fresh weight of plant per tank, respectively.

\subsection{Statistical analysis}

Time series data (nutrients and chlorophyll a) were statistically tested for effects of treatment, time and their interactions by repeated measurements ANOVA (rmANOVA) after checking for normality and homogeneity of variance in the samples and residuals. If the assumption of sphericity of the variance-covariance matrices of the rmANOVA analyses was violated, the degrees of freedom were Huyn-Feldt corrected, resulting in an adjustment of the significance of the $F$ ratio. RGR was statistically tested by student $t$-test after checking for normality and homogeneity. All comparisons were performed 
Table 1. Summary of rmANOVA results on the effects of different treatment on the concentrations of total nitrogen (TN), total dissolved nitrogen (TDN), total phosphorus (TP), total dissolved phosphorus (TDP), chlorophyll $a$ of water (W-Chl- $a$ ) and chlorophyll $a$ of periphyton (PChl-a).

\begin{tabular}{lrrrrrr}
\hline \multicolumn{1}{c}{ Effects } & TN & TDN & TP & TDP & W-Chl- $a$ & P-Chl- $a$ \\
\hline Shrimp & $\mathbf{0 . 0 2 8}$ & 0.063 & $\mathbf{0 . 0 0 1}$ & 0.112 & $<\mathbf{0 . 0 0 1}$ & $\mathbf{0 . 0 4 7}$ \\
Time & $\mathbf{0 . 0 0 1}$ & $<\mathbf{0 . 0 0 1}$ & $<\mathbf{0 . 0 0 1}$ & $\mathbf{0 . 0 2 5}$ & 0.093 & $\mathbf{0 . 0 0 1}$ \\
Shrimp $\times$ Time & 0.859 & 0.118 & $\mathbf{0 . 0 1 6}$ & $\mathbf{0 . 0 1 3}$ & 0.126 & 0.088 \\
\hline
\end{tabular}

Notes: Values indicate probability levels; values in bold are below significance level (0.05).
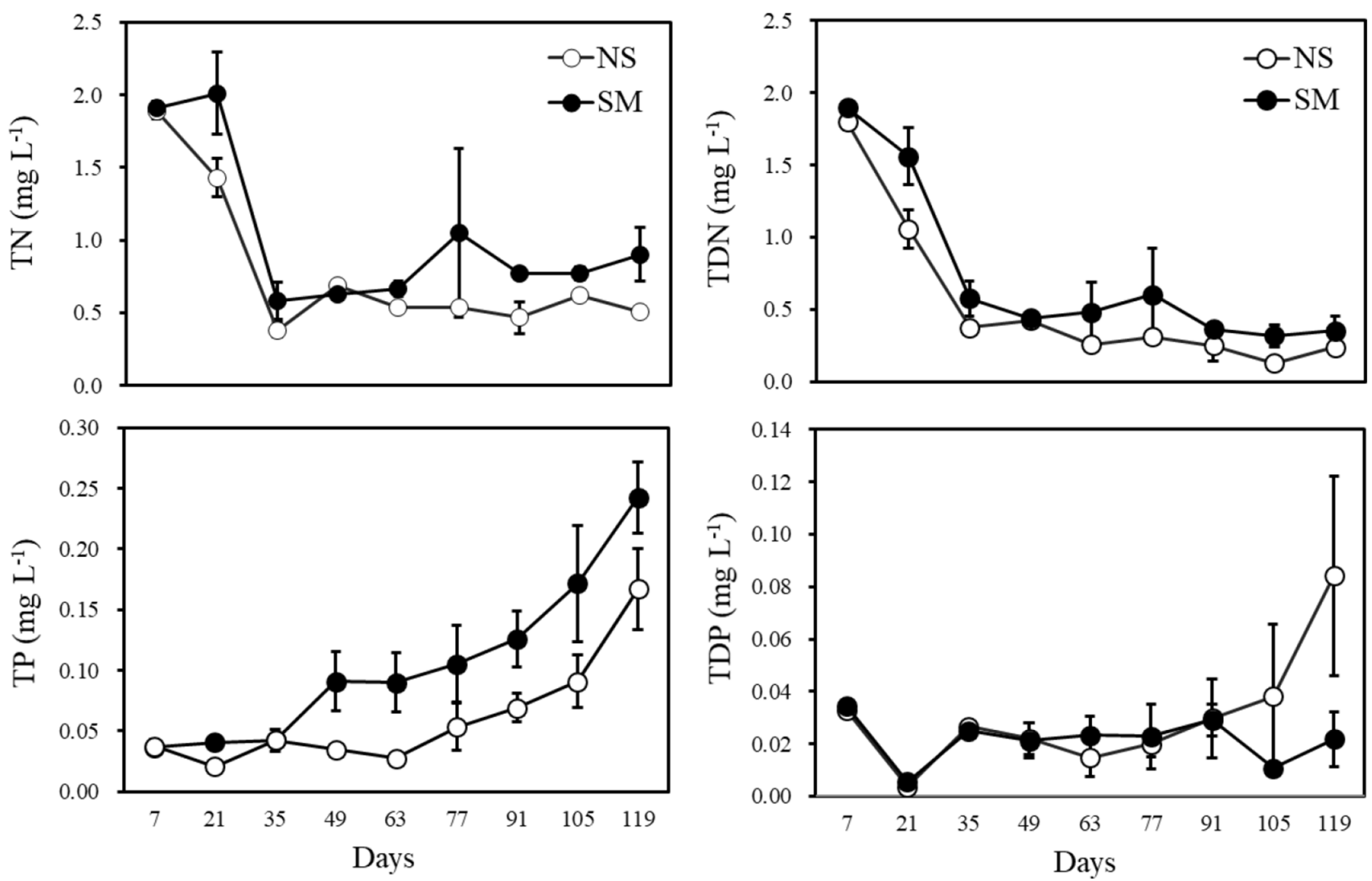

Fig. 1. Variations in nutrients during the experiment $(\mathrm{NS}=$ macrophytes without shrimp; $\mathrm{SM}=$ macrophytes with shrimp). Values represent mean \pm SE.

with the statistical package SPSS version 19.0 (IBM Corporation, Somers, NY, USA).

\section{Results}

\subsection{Changes in water nutrients and Chl-a}

The concentrations of total nitrogen (TN), total phosphorus (TP) and chlorophyll $a$ (W-Chl- $a$ ) in water were significantly higher in tanks with shrimps (SM treatment) than tanks without shrimps (NS treatment), while total dissolved nitrogen (TDN) and total dissolved phosphorus (TDP) concentrations were not significantly different between NS and SM treatments (Tab. 1; Fig. 1).
Mean concentrations of Chl- $a$ in tank water in the NS treatment were $5.09 \pm 4.04 \mathrm{mg} \mathrm{L}^{-1}$, significantly lower than the $11.78 \pm 7.73 \mathrm{mg} \mathrm{L}^{-1}$ observed in the SM treatment water (Tab. 1; Fig. 2).

\subsection{Changes in the biomass of periphyton (Chl-a)}

Variations in periphyton biomass (Chl- $a$ ) over the course of the experiment are shown in Figure 3. The mean Chl- $a$ content of periphyton on the leaves of $V$. denseserrulata in the NS treatment was $6.79 \pm 9.23 \mu \mathrm{g} \mathrm{cm}^{-2}$, while that of leaves in the SM treatment was significantly lower, at $3.69 \pm 4.65 \mu \mathrm{g} \mathrm{cm}^{-2}$ (Tab. 1; Fig. 3). 


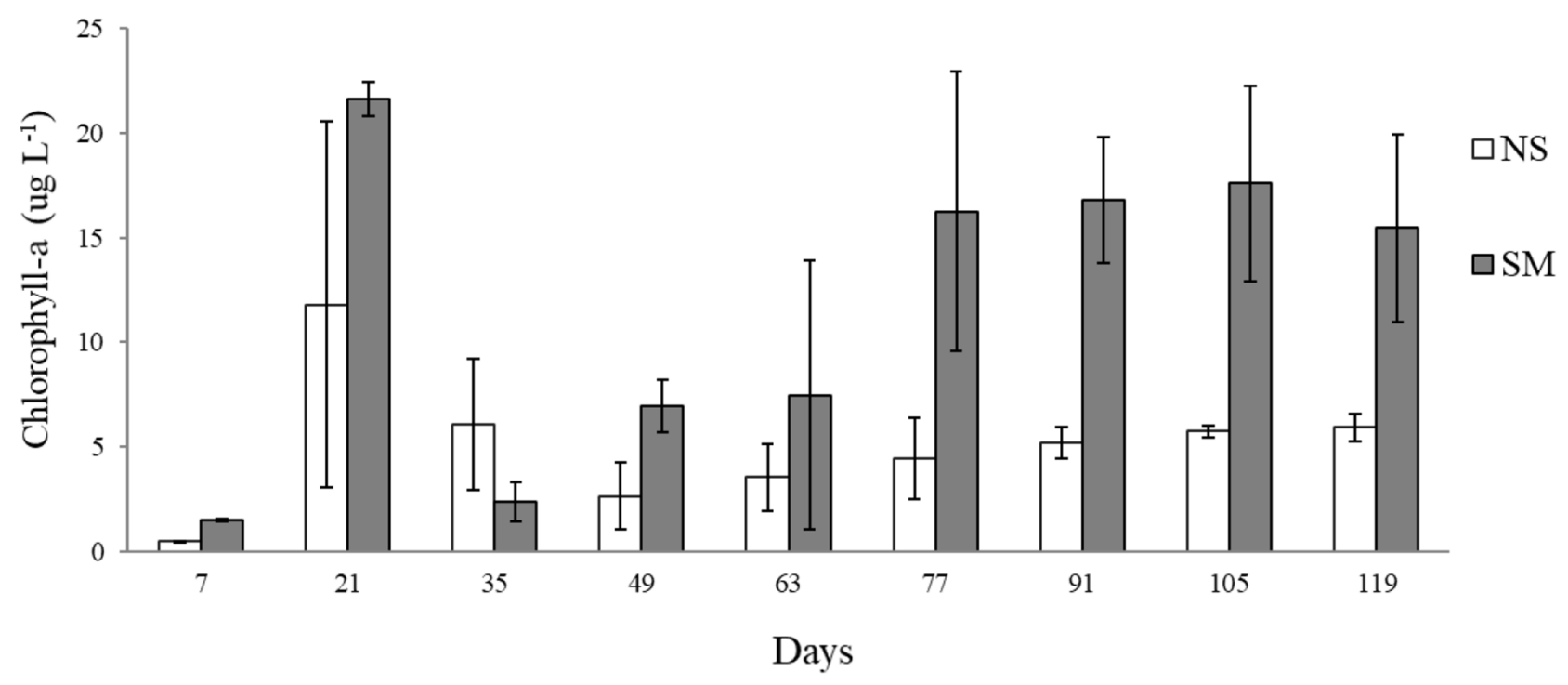

Fig. 2. Variations in the chlorophyll-a (Chl-a) content of tank water (NS= macrophytes without shrimp; $\mathrm{SM}=$ macrophytes with shrimp). Values represent mean $\pm \mathrm{SE}$.

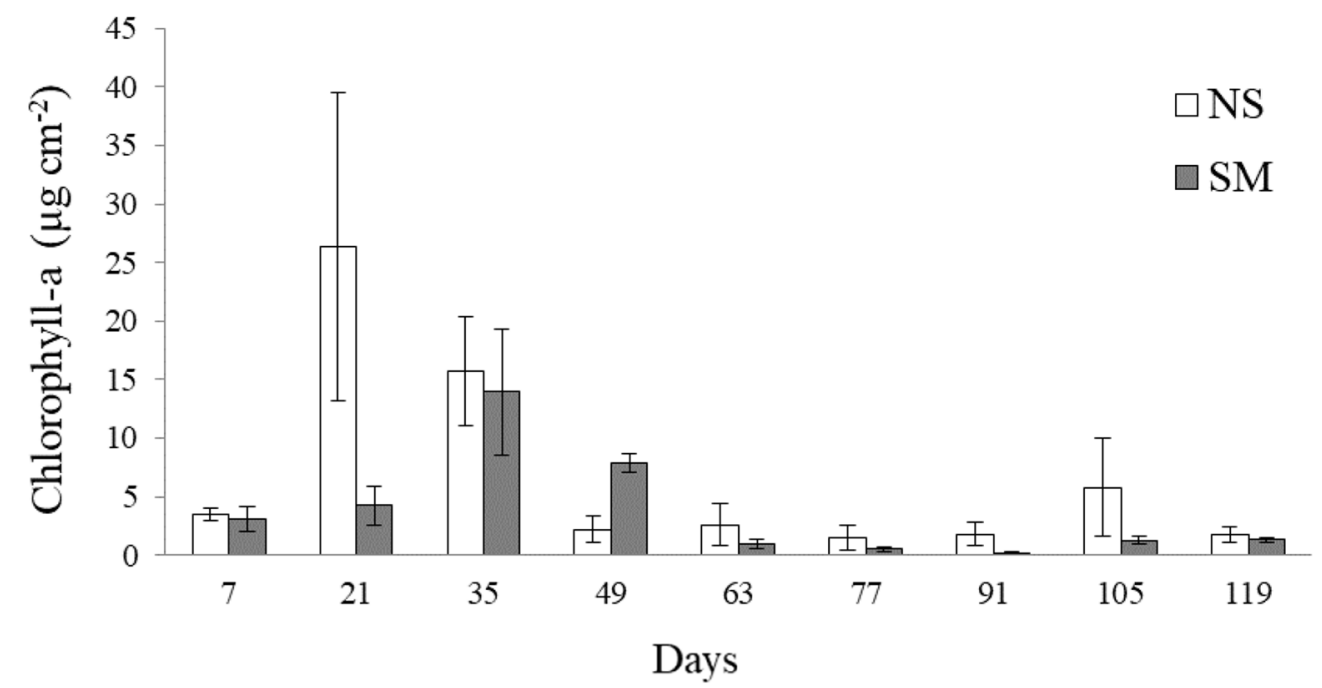

Fig. 3. Variations in periphyton Chl- $a$ on the leaves of $V$. denseserrulata (NS=macrophytes without shrimp; $\mathrm{SM}=$ macrophytes with shrimp). Values represent mean \pm SE.

\subsection{Changes in the growth rate of V. denseserrulata}

At the end of the experiment, the relative growth rates (RGR) of $V$. denseserrulata plants in tanks with shrimp (SM) were significantly higher than the treatment without shrimp (NS) (student $t$-test, $t=-5.485, \mathrm{df}=4, p=0.005$ ). The mean RGR of $V$. denseserrulata was $17.3 \pm 0.2 \mathrm{mg} \mathrm{g}^{-1} \mathrm{~d}^{-1}$ in the SM treatment, while in the NS treatment the mean value was $14.1 \pm 1.0 \mathrm{mg} \mathrm{g}^{-1} \mathrm{~d}^{-1}$ (Fig. 4).

\section{Discussion}

This study demonstrates that the presence of Chinese swamp shrimps $N$. $d$. sinensis leads to a reduction in periphyton biomass on the surface of submerged macrophytes, an effect which is most likely a result of direct consumption of periphyton.

When Yam and Dudgeon (2005) analyzed the carbon and nitrogen stable isotope signatures of two other species of atyid shrimp (Caridina cantonensis and C. serrata) and their potential food sources (leaf litter, fine particulate organic matter, and periphyton), the results indicated that periphyton contributed $>60 \%$ to the biomass of C. cantonensis in unshaded streams between 35 and $60 \%$ to the biomass of Caridina spp. in shaded streams. There is very limited information about the feeding of $N$. d. sinensis in the literature, but an analysis of gut content by Jiang et al. (2010) revealed that the food taken by the species in a stream in central China comprised mainly detritus and benthic algae. In previously reported experiment lasting 30 days, Ye (2017) showed that $N$. $d$. sinensis reduced the density of periphyton on the surfaces of 


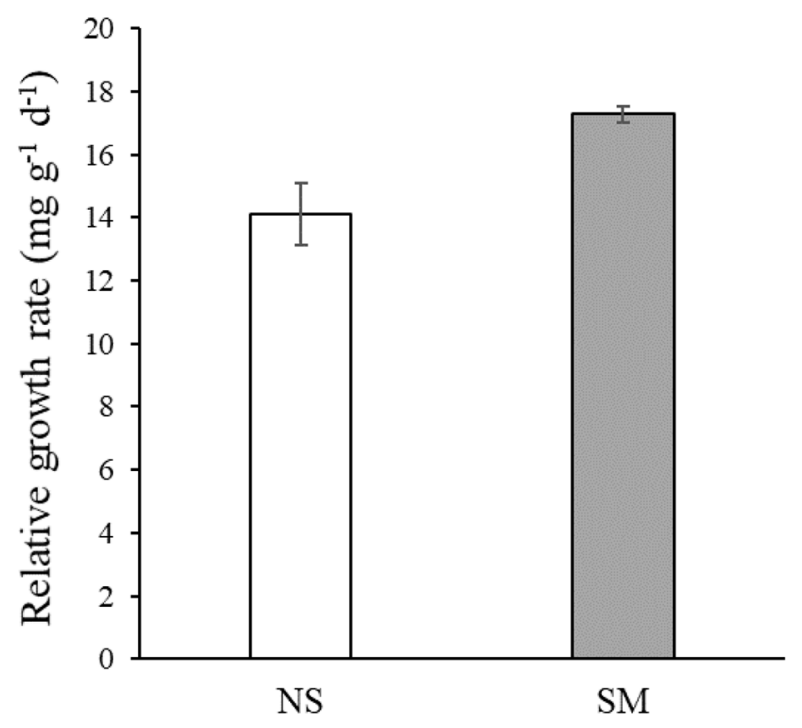

Fig. 4. The relative growth rate of $V$. denseserrulata in the experimental tanks (NS= macrophyte without shrimp; $\mathrm{SM}=$ macrophyte with shrimp), Values represent mean $\pm \mathrm{SE}$.

submerged macrophytes by $>70 \%$. The negative effect of $N$. d. sinensis on periphyton growth agrees with studies of other atyid shrimps in the literature (Pringle et al., 1993; Crowl et al., 2001; Geddes and Trexler, 2003).

The presence of $N . d$. sinensis was seen to enhance the growth rate of submerged macrophyte $V$. denseserrulata under experimental conditions. Overgrowth of periphyton on leaf surfaces is known to reduce the light availability to macrophytes (Carignan and Kalff, 1980; Sand-Jensen and Borum, 1984), resulting in reduced growth and even loss of submerged plants (Daldorph and Thomas, 1995; Jones et al., 2002; Li et al., 2008). Asaeda et al. (2004) also showed that $N$. d. sinensis is able to enhance the growth of submerged macrophyte Potamogeton perfoliatus by removing the periphyton attached to the plants. The experiments of $\mathrm{Li}$ et al. (2008) showed that grazing by the snail Bellamya aeruginosa led to a decrease in periphyton biomass and a 6 to 8 -fold increase in the growth rate of the submerged macrophyte Vallisneria spiralis relative to a snail-free control treatment. Furthermore, Jones and Sayer (2003) showed that in plant-dominated lakes, periphyton appears to have a stronger influence on plant growth than phytoplankton. Thus the removal of periphyton from the surface of $V$. denseserrulata by $N$. $d$. sinensis in the current experiment is likely to be the cause of the observed increase in plant growth rate.

An additional or alternative factor in the increased growth of $V$. denseserrulata in shrimp treatments may be linked to increased nutrient concentrations. Total nitrogen and total phosphorus concentrations were significantly higher in shrimp treatments than in tanks without shrimps. The presence of omnivorous shrimps is known to increase water nutrient concentrations through excretion and sediment resuspension (Takahashi and Ikeda, 1975; Pringle et al., 1993), but since species of Vallisneria obtain most of their nutrient requirement from the sediments via well-developed root systems (Zhang et al., 2010), the influence of nutrient in the water is likely to be limited. The increase in TN and TP in the water nutrients did not appear to exert a direct effect on periphyton biomass in our study. An earlier study by Geddes and Trexler (2003) recorded a positive correlation between the biomass of periphyton and the biomass of omnivorous shrimp (Palaemonetes paludosus) grazing on it, a phenomenon which was attributed to increased nutrient availability mediated by the shrimps. In our study, however, it seems the influence exerted by shrimps is via grazing, rather than nutrient regeneration.

Further analysis of Chl- $a$ in the water in our mesocosms reveals significantly greater phytoplankton biomass in shrimp treatments than in non-shrimp treatments. The increase in phytoplankton is likely due to the elevated nutrient concentrations associated with $N$. $d$. sinensi presence. It is well-known from the literature that high biomasses of phytoplankton limit light penetration and that this shading effect is detrimental to submerged macrophyte growth in eutrophic waters (Jupp and Spence, 1977; Wetzel, 2001). In our study, however, the growth rates of submerged macrophytes in the shrimp treatments showed an increase rather than a decrease. As discussed previously, this increased growth is most likely a result of reduced periphyton due to shrimp grazing, and our results suggest periphyton exerts a more significant controlling effect on the growth of submerged macrophytes than phytoplankton in this case.

Our results have implications for the management and restoration of shallow lakes, which often involves the reestablishment and maintenance of submerged macrophytes essential in establishing clear water conditions. Our study shows that $N$. $d$. sinensi are able to reduce periphyton and increase the growth of submerged macrophytes. Stocking with $N$. d. sinensi may therefore be beneficial for the growth of submerged macrophytes, but the potential for increases in nutrient concentration, phytoplankton biomass and water turbidity must also be considered and further studies are needed to see if such effects of $N$. $d$. sinensi are density or water depth dependent.

In conclusion, our study showed that $N$.d. sinensi could reduce the biomass of periphyton on the leaves of the submerged macrophyte $V$. denseserrulata, while increasing the biomass of phytoplankton. Increasing growth rates of $V$. denseserrulata under these conditions suggest that periphyton exerts a stronger limiting effect on submerged macrophyte growth than phytoplankton in our experimental systems.

Acknowledgements. This study was funded by the Natural Science Foundation of China (grant No.41471086). We are grateful to Amy-Jane Beer for the English improvements of this manuscript. JY and ZL designed the study, JY conducted the sampling, JY, ZL, XZ, PZ, and YT conducted the data analyses and wrote the paper.

\section{References}

Asaeda T, Sultana M, Manatunge J, Fujino T. 2004. The effect of epiphytic algae on the growth and production of Potamogeton perfoliatus L. in two light conditions. Environ Exp Bot 52: 225-238.

Carignan R, Kalff J. 1980. Phosphorus sources for aquatic weeds: Water or sediments?. Science 207: 987-989.

Crowl TA, McDowell WH, Covich AP, Johnson SL. 2001. Freshwater shrimp effects on detrital processing and nutrients in a tropical headwater stream. Ecology 82: 775-783. 
Daldorph PWG, Thomas JD. 1995. Factors influencing the stability of nutrient-enriched freshwater macrophyte communities: The role of sticklebacks Pungitius pungitius, and freshwater snails. Freshw Biol 33: 271-289.

Englund RA, Cai Y. 1999. The occurrence and description of Neocaridina denticulata sinensis (Kemp, 1918) (Crustacea: Decapoda: Atyidae), a new introduction to the Hawaiian Islands. Bish Mus Occas Pap 58: 58-65.

Geddes P, Trexler JC. 2003. Uncoupling of omnivore-mediated positive and negative effects on periphyton mats. Oecologia 136 : 585-595.

Hough RA, Fornwall MD, Negele BJ, Thompson RL, Puttet DA. 1989. Plant community dynamics in a chain of lakes: Principal factors in the decline of rooted macrophytes with eutrophication. Hydrobiologia 173: 199-217.

Jaynes ML, Carpenter SR. 1986. Effects of vascular and nonvascular macrophytes on sediment redox and solute dynamics. Ecology 67: 875-882.

Jeppesen E, Søndergaard M, Mortensen E, Kristensen P. 1990. Fish manipulation as a lake restoration tool in shallow, eutrophic temperate lakes 1: Cross-analysis of three Danish case-studies. Hydrobiologia 200/201: 205-218.

Jiang J, Wen F, Deng S, Yan Y. 2010. Population dynamics, annual production and trophic basis analysis of the dominant species Neocaridina denticulata sinensis (Kemp) in Hujiaxi Stream. Acta Hydrobiol Sin 3: 569-574.

Jin X, Tu Q. 1990. The standard methods for observation and analysis in lake eutrophication, 2nd ed. Beijing, China: Chinese Environmental Science Press.

Jones JI, Sayer CD. 2003. Dose the fish-invertebrate-periphyton cascade precipitate plant loss in shallow lakes? Ecology 84: 2155-2167.

Jones JI, Young JO, Eaton JW, Moss B. 2002. The influence of nutrient loading, dissolved inorganic carbon and higher trophic levels on the interaction between submerged plants and periphyton. $J$ Ecology 90: 12-24.

Jupp BP, Spence DHN. 1977. Limitations on macrophytes in a eutrophic lake, Loch Leven: I. Effects of phytoplankton. J Ecology 65: 175-186.

Li C, Li Y, Xie Q, Pen C. 1990. A study on the maximum sustained yield of the macrura's shrimp in the Poyang Lake and its development, utilization. Jiangxi Sci 8: 28-33.

Li K, Liu Z, Gu B. 2008. Persistence of clear water in a nutrientimpacted region of Lake Taihu: The role of periphyton grazing by snails. Fundam Appl Limnol/Arch Hydrobiol 173: 15-20.

Liu Z, Hu J, Zhong P, Zhang X, Ning J, Larsen SE, Chen D, Gao Y, He $\mathrm{Hu}$, Jeppesen E. 2018. Successful restoration of a tropical shallow eutrophic lake: Strong bottom-up but weak top-down effects recorded. Water Res 146: 88-97.

Moulton TP, Souza ML, Brito EF, Braga MRA, Bunn SE. 2012. Strong interactions of Paratya australiensis (Decapoda: Atyidae) on periphyton in an Australian subtropical stream. Mar Freshw Res 63: $834-844$.
Oh CW, Ma CW, Hartnoll RG, Suh HL. 2003. Reproduction and population dynamics of the temperate freshwater shrimp, Neocaridina denticulata denticulata (De Haan, 1844), in a Korean stream. Crustaceana 76(8): 993-1015.

Phillips G, Willby N, Moss B. 2016. Submerged macrophyte decline in shallow lakes: What have we learnt in the last forty years? Aquat Bot 135: 37-45.

Pringle CM, Blake GA, Covich AP, Buzby KM, Finley A. 1993. Effects of omnivorous shrimp in a montane tropical stream: Sediment removal, disturbance of sessile invertebrates and enhancement of understory algal biomass. Oecologia 93: 1-11.

Rao W, Ning J, Zhong P, Jeppesen E, Liu Z. 2015. Size-dependent feeding of omnivorous nile tilapia in a macrophyte-dominated lake: Implications for lake management. Hydrobiologia 749: 125-134.

Sand-Jensen K, Borum J. 1984. Epiphyte shading and its effect on photosynthesis and diel metabolism of Lobelia dortmanna L. during the spring bloom in a Danish lake. Aquat Bot 20: 109-119.

SEPA. 2002. Analytical methods for water and wastewater monitor, 4th ed. Beijing, China: Chinese Environmental Science Press.

Souza ML, Moulton TP. 2005. The effects of shrimps on benthic material in a Brazilian island stream. Freshw Biol 50: 592-602.

Sultana M, Asaeda T, Azim ME, Fujino T. 2010. Morphological responses of a submerged macrophyte to epiphyton. Aquat Ecol 44: 73-81.

Takahashi M, Ikeda T. 1975. Excretion of ammonia and inorganic phosphorus by Euphausia pacifica and Metridia pacifica at different concentrations of phytoplankton. J Fish Board Can 32 (11): 2189-2195.

van Donk E, van de Bund WJ. 2002. Impact of submerged macrophytes including charophytes on phyto-and zooplankton communities: Allelopathy versus other mechanisms. Aquat Bot 72: 261-274.

Weiperth A, Gabris V, Danyik T, Farkas A, Kurikova P, Patoka J, Kouba A. 2019. Occurrence of non-native red cherry shrimp in European temperate waterbodies: A case study from Hungary. Knowl Manag Aquat Ecosyst 420: 9.

Wetzel RG. 2001. Limnology: Lake and river ecosystems. 3rd Ed. San Diego, USA: Academic Press, p. 1006, ISBN: 9780127447605.

Yam RSW, Dudgeon D. 2005. Stable isotope investigation of food use by Caridina spp. (Decapoda: Atyidae) in Hong Kong streams. $J$ North Am Benthol Soc 24: 68-81.

Ye J. 2017. The effects of Atyid shrimp on periphytic algae, Vallisneria natans and water quality. Thesis of Master of Sciences, Jinan University, Guangzhou, China.

Yu J, Liu Z, Li K, Chen F, Guan B, Hu Y, Zhong P, Tang Y, Zhao X, He H, Zeng H, Jeppesen E. 2016. Restoration of shallow lakes in subtropical and tropical China: Response of nutrients and water clarity to bio-manipulation by fish removal and submerged plant transplantation. Water 8: 438.

Zhang L, Li K, Liu Z, Middelburg JJ. 2010. Sedimented cyanobacterial detritus as a source of nutrient for submerged macrophytes (Vallisneria spiralis and Elodea nuttallii): An isotope labeling experiment using ${ }^{15}$ N. Limnol Oceanogr 55: 1912-1917.

Cite this article as: Ye J, Tang Y, Zhang X, Zhong P, Liu Z. 2019. Omnivorous shrimp Neocaridina denticulata sinensis enhances the growth of submerged macrophyte Vallisneria denseserrulata. Knowl. Manag. Aquat. Ecosyst., 420, 32. 